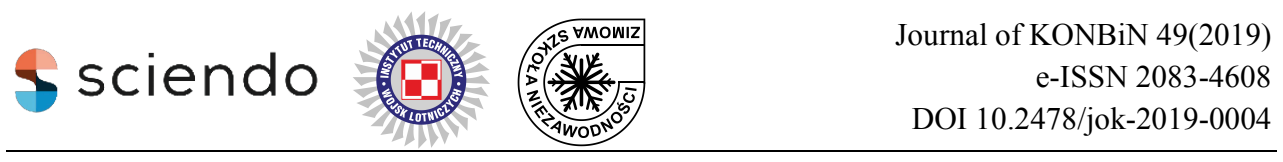

Łukasz WOLNIEWICZ

Wroctaw University of Science and Technology (Politechnika Wroctawska)

\title{
EVALUATION OF TRAIN CREWS SCHEDULE IN TERMS OF ROBUSTNESS
}

\section{Ocena harmonogramu pracy drużyn pociągowych w aspekcie odporności}

\begin{abstract}
The evaluation of team work schedules in complex rail transport conditions is related to the robustness of individual solutions. In rail systems there are many aims that are important for users. One of the most important aims is to find a feasible solution. It is characterized by the non-conflicting schedule with another train, minimizing the travel time of the trainset and taking into account the priority of train. The problem of responding to delays in terms of reorganisation of work, prevention of delay propagation and real-time schedule changes is important. Schedules are built in a way that ensures the best use of work time. This has a negative impact on critical situations. The study analysed the changes of the conductor's team to another train depending on the buffer time provided in work plan, real time needed for change and train delays.
\end{abstract}

Keywords: scheduling, robustness, rating

Streszczenie: Ocena harmonogramów pracy drużyn w złożonych warunkach transportu kolejowego jest zwiazana z odpornościa na zakłócenia poszczególnych rozwiazań. Powinny się one charakteryzować brakiem konfliktu w harmonogramie z innym pociagiem, minimalizowaniem czasu przejazdu sktadu oraz uwzględnieniem priorytetu przejazdu pociagów. Szczególnie istotny jest problem reagowania na opóźnienia pod kątem reorganizacji pracy, zapobiegania propagacji opóźnień oraz bieżacych zmian w harmonogramie. Harmonogramy budowane sa w sposób zapewniający najlepsze wykorzystanie czasu przeznaczonego na pracę. Wptywa to negatywnie na wystepujace sytuacje krytyczne. W pracy przeanalizowano przesiadki drużyny konduktorskiej do innego pociagu w zależności od przewidzianego w planie pracy czasu buforowego oraz zmierzonego czasu potrzebnego na przesiadkę i zbadanych opóźnień pociagów.

Słowa kluczowe: harmonogramowanie, odporność, ocena 


\section{Introduction}

The literature distinguishes between different measures investigating the properties of schedules. The measures of chronometric robustness can be divided according to the degree of implementation. Ex-ante measures are related to the characteristics of the timetable or work plan at the scheduling. Ex-post measures, on the other hand, are based on operational conditions after the implementation of the solution to be implemented. At the plan application stage to the real system, indicators are correlated with the degree of robustness to schedule disturbances available in generated temporary solutions in response to disturbances. The authors of the publication mainly focus on time disturbances, i.e. situations in which the journey lasts longer than expected or the start time of the action is delayed. The problem of "domino effect" in case of interferences has also been noted. During the realization of the work schedules of the conductor teams, the dependent actions and the human factor in the form of a dispatcher have a great influence on the work schedules. The dispatcher decides to change the work plan of individual teams if it is not possible to move between the rolling stock. Improvement of robustness to disruptions in teams' work schedules includes continuous analysis of processes, inventory of disruptions and forecasting their effects. For proper planning of work, the most accurate data about the current system are indicated, which allows for forecasting the possibility of critical states.

\section{Scheduling robustness}

The concept of robustness is appropriate in different fields of science. It has a different meaning depending on the field. Its origins date back to the modern decision-making theory developed in the 1950s and the use of scenario analysis and the Maximin Wald model as a tool to prevent unstable cases. It became an independent discipline as a robust optimization in the 1970s. At the same time, it has developed in several scientific and technological fields. The concept of robustness has been used for years in statistics and operational research [1].

In planning robustness refers to the work schedule of machines, people and vehicles. According to [18] it means the ability to cope with unexpected problems without significant schedule modifications. In the article [15] robustness is defined as a tolerance to a certain degree of uncertainty, while in [17] it is the maximum initial delay possible to occur without causing interference to other vehicles. This definition refers to the design of timetables and work schedules of conductor teams 
and drivers. Their schedule is closely related to it. In [2] the authors define robustness as the ability of a schedule to withstand design errors, changes in parameters and operating conditions. The author of publication [9] defined the schedule as robust when delays from one period do not spread to the next period. The approach is based on the fact that the schedule is periodic. In [16] robustness refers to "robustness to inaccuracy". Two definitions of robustness are provided. The first definition is the percentage of interference smaller than a certain unit of time that the timetable is able to tolerate without any current modifications. Disturbance refers here to one single event (delay) in the implementation of the schedule. The second definition refers to whether the schedule can return to the initial stage unchanged by the disturbance for a limited period of time.

In the field of planning, the problem of robustness can come from a variety of sources: imprecise activity times, reduced resource capacity (e.g. due to machine breakdowns), new production tasks, reorder of activities and operators. The solution to the scheduling problem is to take into account the impact of external events. This guarantees the stability of flexible schedules. In the event of a disruption, a flexible schedule allows allocation of activities. This provides the basis for responding to unexpected disturbances. The article [15] focuses on building partially readymade solutions (time-consistent), which are also part of the overall schedule. The goal is not to create a single schedule, but to define a set of schedules, which are called partial order schedule (POS). POS planning for a given problem is a graph in which there are nodes that are actions, and the edges indicate partial limitations between pairs of actions, such that any temporary solution possible at a given moment to apply is consistent with the entire schedule.

Authors [15] use the term robustness as the ability of the schedule to accept small delays. A robust schedule is one that allows trains to regain punctuality when small delays occur and prevents the spread of disruption to the network. In a robust timetable trains should be able to maintain their originally scheduled running hours with low delays and not cause irreversible delays to other trains. The challenge in creating robust timetables is twofold: a measure of robustness is required that accurately reflects the ability to deliver the schedule, and a method that suggests how to modify the schedule to increase robustness in line with other specified planning objectives. Before the schedule is implemented in a simulation environment or implemented in reality, it is difficult to predict how rail traffic will react to disruptions and the magnitude of delays that may occur. Europe's rail networks are heavily congested in many points of the network. This results in a delay-sensitive traffic system with low robustness. One of the main challenges is to assess its robustness and to define strategies to reduce its sensitivity to interference. The most common way to do this is to analyze the schedule in terms of bandwidth and eliminate critical 
points. Existing robustness measures are useful when comparing different timetables with respect to their robustness. However, they are not so useful to suggest directly where improvements should be made. The authors [15] propose a new indicator taking into account the critical concept. It is defined as the inverse of the sum of the shortest differences in distance between vehicles. This concept allows to find weak points in the schedule. The quantitative assessment determines the validity at critical points. The results of experimental studies in which the critical points benchmark was performed are presented. The conclusions of the evaluation were the need to pay attention to the points in timetables where trains enter the railway line or overtake each other. From the point of view of robustness, the time difference between them is important. It is also proposed to delay trains already delayed by extending station stops in order to allow punctual trains to pass through.

In rail transport, robustness issues can be subdivided into timetables and work schedules of people and rolling stock plan. The nature of the problem of the current modification of the timetable is multifunctional due to the numerous contradictory use of resources and quality assurance issues for passengers. Therefore, multi-target approaches generate more robust alternatives [8].

Disruption causes the primary delay of one train, which often promotes it to other trainsets as secondary. Therefore, one of the main requirements is to reduce the promotion of secondary delays on the network. Strategies related to the robustness of the disruption response are divided into a priori and a posteriori strategies:

- the ability to absorb primary delays by including time buffers at the design stage (a priori) provides greater flexibility in the schedule,

- reduction of secondary delays through dispatching activities (a posteriori) $[6,7,10,12]$.

\section{Robustness indicators used in rail transport}

The measures of robustness of train schedules can be divided into two groups: ex-ante measures related to timetable characteristics and ex-post measures which are based on rail line operational conditions. The operating conditions may not be calculated unless the schedule is actually realized or simulated with interference on rail line. Timetable measures can be calculated and compared at an early stage in the planning process without knowledge of operational disturbances. Fig. 1 shows the basic difference between the two groups.

In order to assess the robustness of alternative schedules arranged after a disturbance has occurred, two measures have been introduced in publications [3, 14], which examine their properties. The first fldt metric (1) is correlated with the degree 
of robustness of the schedule available in the generated solutions. The higher the fldt value, the lower the chance of a "domino effect". The dsrp index (2) can alternatively be seen as a result of a simulation of a solution in response to one disturbance event.

$$
f l d t=\sum_{h \neq 1} \frac{\left|d\left(e_{a h}, s_{a l}\right)+d\left(s_{a l}, e_{a h}\right)\right|}{H \cdot n \cdot(n-1)} \cdot 100
$$

$\mathrm{H} \quad-$ duration of all activities

$\mathrm{n}-$ number of activities

$d\left(t_{p 1}, t_{p 2}\right)$ - time between two points in time

$$
d s r p=\frac{1}{n} \sum_{i=1}^{n} \frac{\text { slack }_{a i}}{\text { num }_{\text {changes }\left(a_{i}, \Delta a_{i}\right)}}
$$

Slack $\mathrm{ai}_{\mathrm{i}}$ - elasticity of each activity (ability to absorb changes)

Num - propagation effect of relocated activities

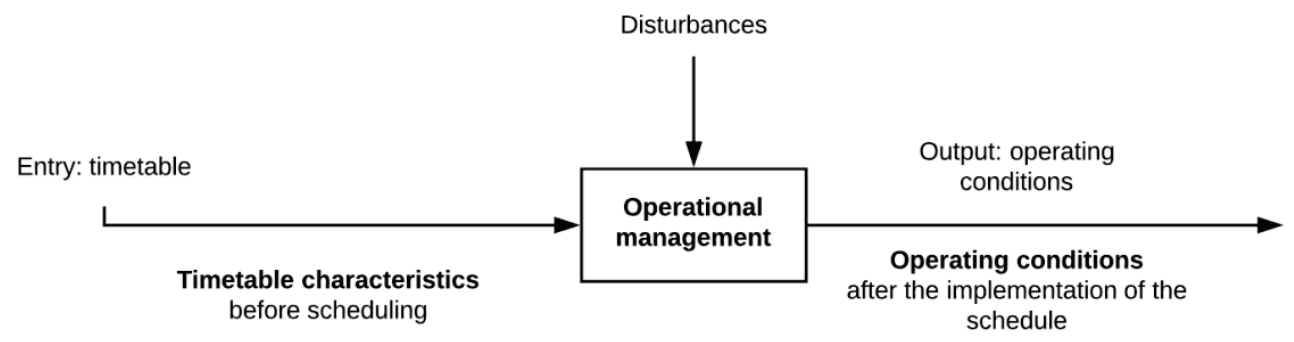

Fig. 1. Two types of robustness measures used for the analysis timetable robustness

The authors of the publication concentrate only on time disturbances (situations where the journey takes longer than expected or the start time of the action is delayed). The relationship between the activities is not analysed in the evaluation.

\section{Dependent operations}

Interchanges in rail transport may be defined as dependent operations. Such links in the timetable shall be included in the area of production planning. They consist in manufacturing a given element on several machines in a process line $[5,19]$. This chain is more flexible (easy to reorganise) and there are no such restrictions as in rail transport. According to [13], transfers between trains are limited 
by the timetable to which the rolling stock and train crews' work schedules are assigned. Infrastructure conditions and travel time combined with the frequency of rolling stock are another constraint. In the event of disruption, trains may interact with each other depending on the infrastructure. Rigid track systems are closely related to the designated runway [11]. According to [3], traffic management and reorganisation in the event of disruption is essential to ensure a high quality service for passengers. The work schedule of the conductor teams is characterised by the following parameters:

- travel time,

- working hours,

- break time,

- time of activities related to preparation for work,

- time of activities related to the end of work,

- the timing of the reorganisation of the timetable,

- work starting in the home station,

- work ending at the home station,

- work starting in the station,

- work ending at the station,

- a set of dependent journeys,

- a set of journeys within the rolling stock schedule (sequential),

- a set of all journeys,

- team transition times (between trains),

- time of taking over and handover of the train, possible brake test,

- the possible maximum duration of the journey,

- the minimum duration of the journey,

- time of departure,

- time of arrival,

- the maximum duration of work on a day,

- the minimum duration of work on a day,

- time spent on travel,

- time generating the propagation of disturbances.

Using a generalised Petri network with initial marking $\mathrm{M}_{0}=(1,0,0,0,0,1,1)$ the transfer process was modelled in a non-deterministic way (fig. 2). This network reaches three dead markings interpreted as the train being taken over by the conductor's team at the end of the interchange. It is conservative because the number of markers does not change during operation. 


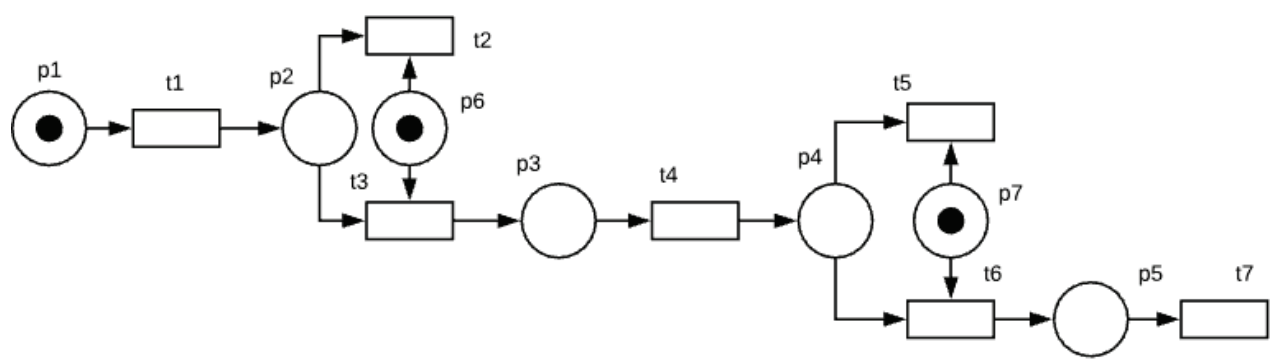

Fig. 2. Non-deterministic interchange model based on the Petri network

Below is an explanation of the markings used in fig. 2:

$\mathrm{p}_{1}$ - rail travel,

$\mathrm{p}_{2}$ - interchange,

$\mathrm{p}_{3}-$ contact with the dispatcher,

$\mathrm{p}_{4}$ - interchange information,

$\mathrm{p}_{5}$ - alight from the train,

$\mathrm{p}_{6} \mathrm{i}_{7}$ - provide a single path selection,

$\mathrm{t}_{1}$ - alight,

$\mathrm{t}_{2}$ - taking over a train according to a schedule (on time),

$t_{3}$-impossibility to take over a train according to a schedule,

$\mathrm{t}_{4}$ - searching for an interchange,

$\mathrm{t}_{5}$ - taking over the indicated train,

$\mathrm{t}_{6}$ - travel to another interchange point,

$\mathrm{t}_{7}-$ train takeover.

\section{Schedule analysis for the hub station}

The work schedule of teams with local carrier interchanges for one of the hub stations was analyzed in terms of robustness to delays. This type of transport is characterized by high flexibility of available connections and frequent stops in comparison to long-distance relations.

In order to determine the value of delays that could interfere with the schedule, punctuality was measured for 9608 trains of this carrier (tab. 1).

Table 1

\section{Operational data characteristics for analysed case}

\begin{tabular}{|c|c|c|}
\hline Number of analysed trains & Punctual departures & Delayed departures \\
\hline 9608 & 0,6168 & 0,3832 \\
\hline
\end{tabular}


Fig. 3 shows the probability distribution of train departure from a station with a delay greater than zero, i.e. later than scheduled according to the timetable. The gamma distribution was estimated and confirmed with the Chi-square test at the level of confidence of 0.05 . Finally, the gamma distribution $\Gamma(0,78273,7,538)$ with the function of probability density (3) was used to describe delays in the analysed scenario.

$$
f(x)=\frac{x^{\alpha-1}}{\beta^{\alpha} \Gamma(\alpha)} \exp \left(-\frac{x}{\beta}\right)
$$

$\Gamma$ - Gamma function,

$\alpha$ - shape parameter $(\alpha>0)$,

$\beta$ - scale parameter $(\beta>0)$.

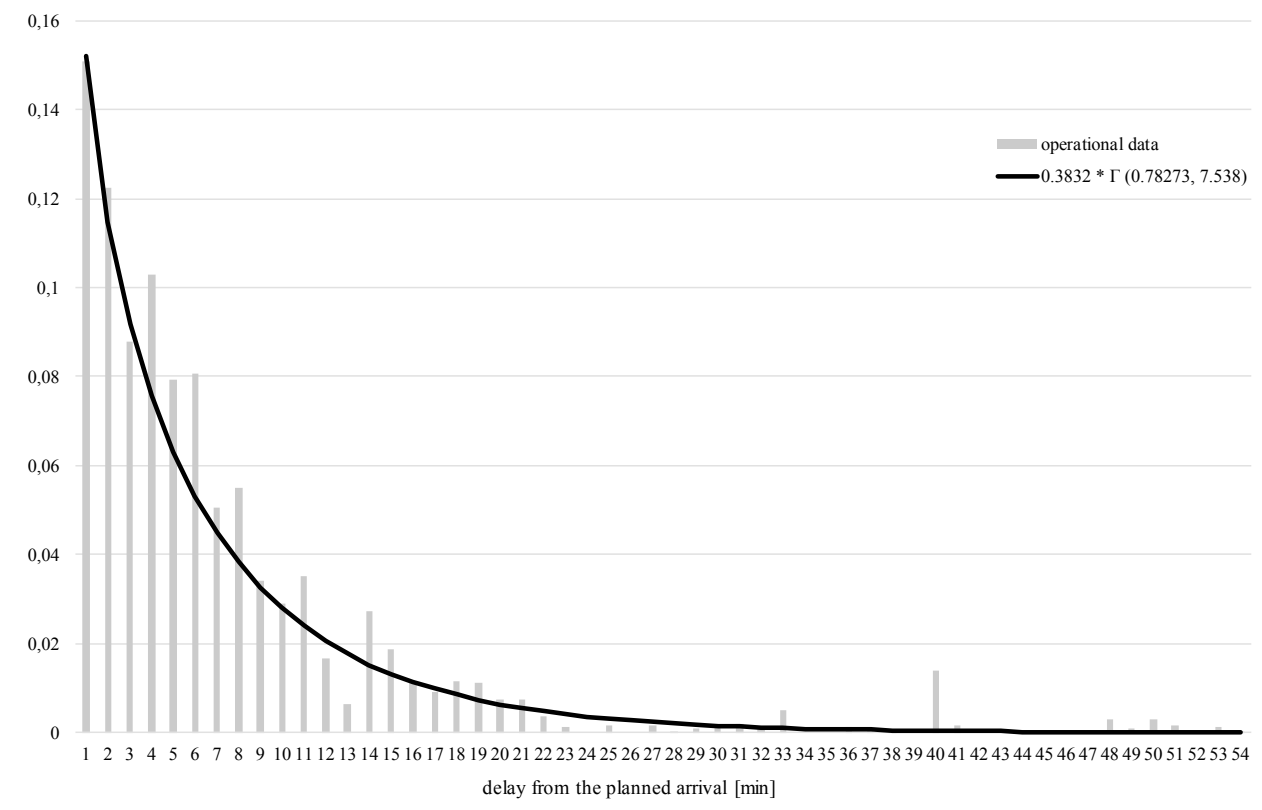

Fig. 3. Empirical distribution of delays and approximate gamma distribution

The probability of not delaying a train was calculated as follows (4):

$$
P_{o}=0,6168+0,3832 \cdot \int_{0}^{t} f(x) d x
$$

where $\mathrm{f}(\mathrm{x})$ is a probability density function describing train delays, in this case $\Gamma$ $(0,78273,7,538)$, where the upper limit $t$ is the difference between the scheduled completion of the first process and the latest finish of the second one. 
In order to verify the time needed for a change of the conductor's team at the analyzed station, the crossing times from the moment the first train stopped to the moment the team entered the target train (the second train) were measured (tab. 2).

Table 2

Operational data characteristics for interchange times

\begin{tabular}{|c|c|c|}
\hline Number of interchanges & Average [min] & Standard deviation [min] \\
\hline 30 & 6 & 2,19 \\
\hline
\end{tabular}

The confidence interval of the average team passage time (5) was determined assuming a confidence factor of 0.95 . The time needed for a change at the station is between 5.22 and 6.78 minutes.

$$
P(5,22<v<6,78)=0,95
$$

The dependent operations preceding and following the change of the team are shown in Fig. 4. First, the conductor team travels by train 69551, from which they will get off at the station and change to the train 69552. At the punctual arrival of both trains, the time between trains (time difference between the arrival of the train 69551 and the departure of the train 69552) is greater than the measured real time needed for the change of train. The real time from the moment of departure from the train 69551 to the moment of entering the train 69552 of the team is defined as a "interchange". Buffer time is associated with security time, which is used in the case of disturbing events to improve schedule robustness. If a train 69551 or 69552 is delayed by a buffer value or a lower or total delay of both trains will be equal to or lower than the buffer value, a change of the conductor team will be feasible. If this process is disturbed due to the greater delay of train number 69551, it is necessary to delay the departure of train number 69552.

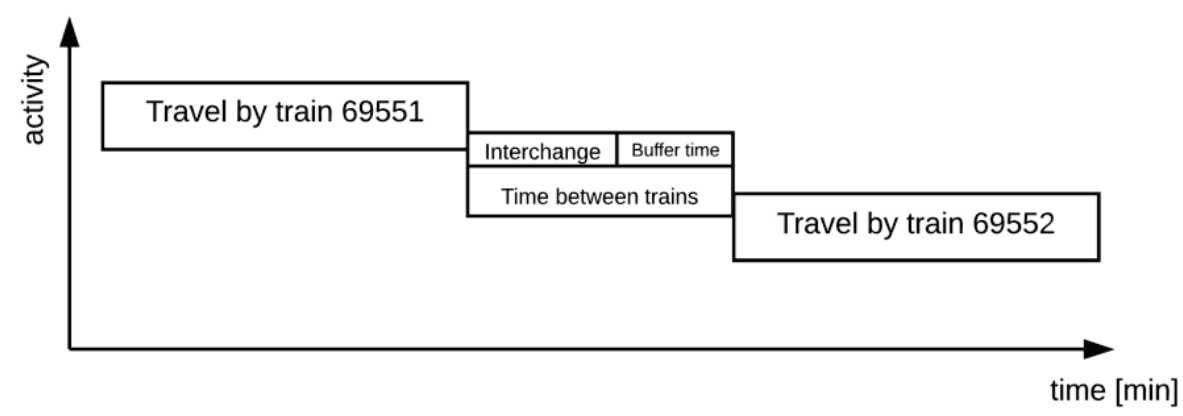

Fig. 4. Interchange between two trains 69551 and 69552 
Work schedules with dependent operations have been tested for robustness to non- punctuality. This concept is defined as the degree of tolerance for train delay that does not result in a change in the work schedule of teams and other trains. Interchange times are in no way specified in railway regulations. Carriers set them in an intuitive way. Fig. 5 shows the time between trains for 10 analysed work plan with planned interchanges at a selected hub station compared to the buffer time, i.e. the value of time between trains reduced by the upper limit of the designated confidence interval for the real time of interchanges at this station. Each work plan has a different buffer time.

The values of probability of train non-delay (4) were calculated depending on the buffer times included in eleven work plan for the analyzed hub station. The results are shown in fig. 6 . The buffer times from 20 minutes for the analyzed data give the greatest guarantee that the previous process will be completed by the time and will not delay the next one. For a buffer of 1 minute, the probability of delay of the next train to which the team interchanges by the previous train, which may be delayed is the highest.

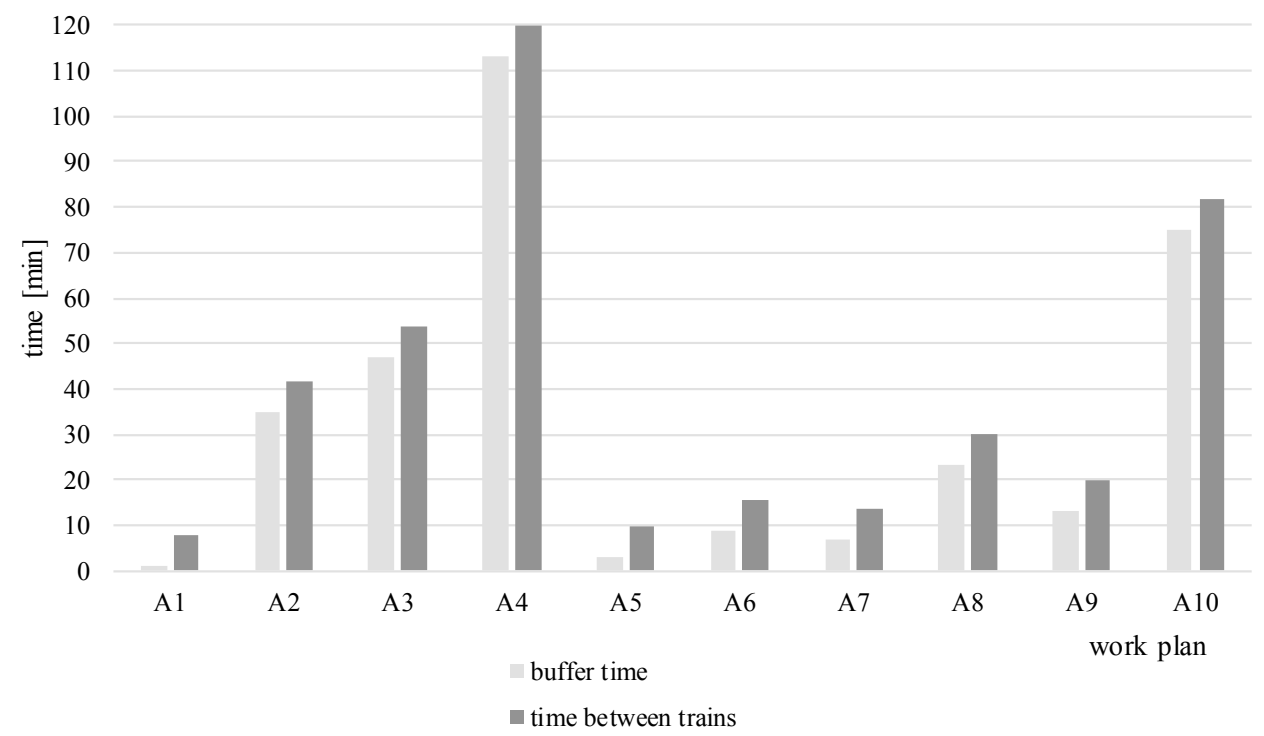

Fig. 5. Comparison of times between trains with buffer time 


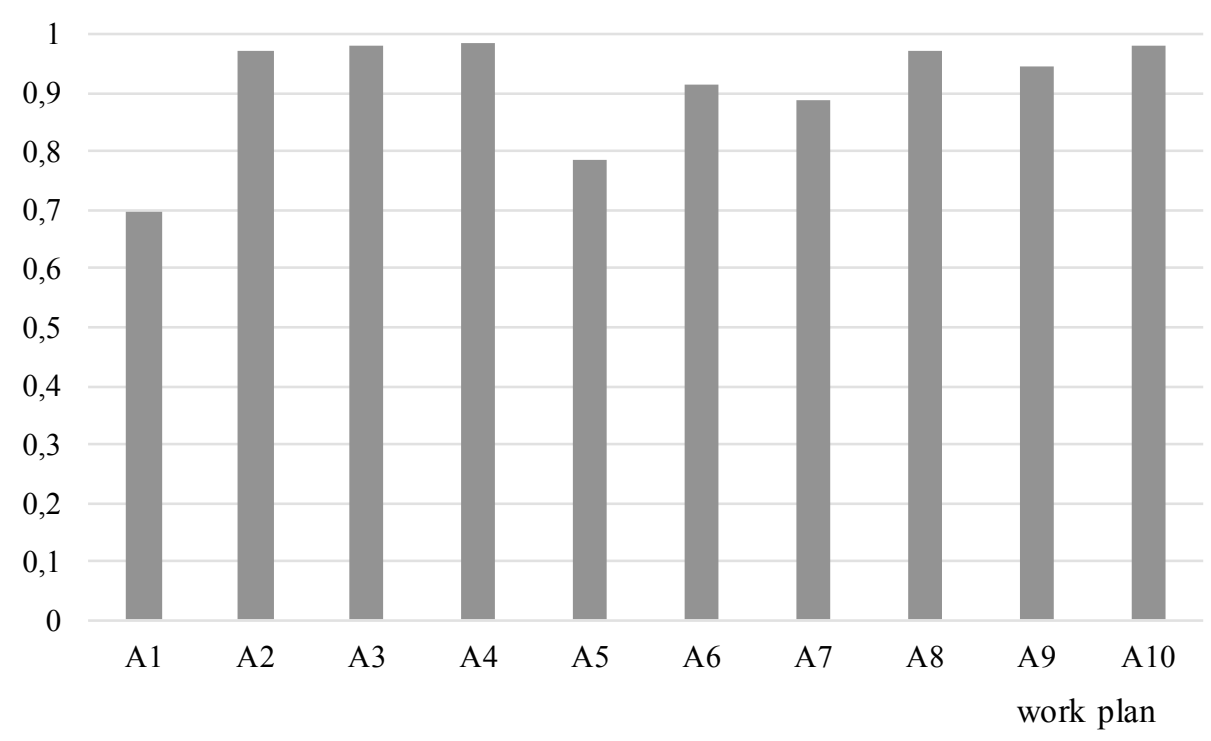

Fig. 6. The probability of not delaying the next train by the previous one

The probability of an interchange is determined by the weak links in the work plan, which indicate the need to modify it, thus becoming a decision criterion. There are methods to eliminate the propagation of delays in the case of the impact of two trains. If the trains are running from opposite directions and the teams are exchanging, the train going on time can be continued and the change to the next station. In the case of longer delays, the step-by-step method can be used. It is based on later trains being taken over by further delayed teams.

\section{Summary}

The research on train delays and real interchanges at the hub station was used to assess the effects of events disrupting the work schedule of conductor teams. Due to the large buffer times, this schedule is characterized by a high degree of robustness to disruptions of dependent operations. In this case problems with an interchange can occur for a buffer time of less than 8 minutes, which is used in three work plans. Interchanges in the other work plans have a probability of no further train delay of 0,9 .

It follows that it is important to implement buffer times appropriate to the traffic conditions when introducing interchanges into the work plans. The analysed 
work plan is characterized by long buffer times, with an average value of 33 minutes.

In the perspective of the next research, it is planned to automate the evaluation tool to a form supporting the construction of work plans on the basis of archive data on disturbing events.

\section{References}

1. Bertsimas D., Sim M.: The Price of Robustness. Operations Research, 52 (1), 2004.

2. Bešinovic N., Goverde R., Quaglietta E., Roberti R.: An integrated micro-macro approach to robust railway timetabling. Transportation Research, Part B 87, 2016.

3. Castillo E., Gallego I., Urena J.M., Coronado J.M.: Timetabling optimization of a mixed double- and single-tracked railway network. Appl. Math. Model. Vol. 35, 2011.

4. Cesta A., Oddi A., Smith S.F.: Profile Based Algorithms to Solve Multiple Capacitated Metric Scheduling Problems. In Proceedings of the 4th International Conference on Artificial Intelligence Planning Systems AIPS-98, 241-223. AAAI Press, 1998.

5. Chergui A., Hadj-Hamou K., Vignat F.: Production scheduling and nesting in additive manufacturing. Computers \& Industrial Engineering, Vol. 126, 2018, DOI 10.1016/j.cie.2018.09.048.

6. D'Ariano A., Pacciarelli D., Pranzo M.: Assessment of flexible timetables in real-time traffic management of a railway bottleneck. Transp. Res. C Emer. 16 (2), 2008.

7. Dewilde T., Sels P., Cattrysse D., Vansteenwegen P.: Defining robustness of a railway timetable. Proceedings of the Fourth International Seminar on Railway Operational Modelling and Analysis RailRome, 2011.

8. Fang W., Yang S., Yao X.: A survey on problem models and solution approaches to rescheduling in railway networks. IEEE Trans. Intell. Transp. Syst. 16 (6), 2015.

9. Goverde R.: Railway timetable stability analysis using max-plus system theory. Transp. Res. Part B 41, 2007.

10. Kroon L.G., Huisman D., Maróti G.: Optimisation models for railway timetabling. In: I. Hansen, J. Pachl (Eds.) Railway Timetable and Traffic, Eurailpress, Hamburg 2008.

11. Kuznetsov N.A., Minashina I.K., Pashchenko F.F., Ryabykh N.G., Zakharova E.M.: Design and Analysis of Optimization Algorithms for Multi-agent Railway Control System. Procedia Computer Science, Vol. 37, 2014, DOI 10.1016/j.procs.2014.08.032.

12. Li X., Shou B., Ralescu D.: Train rescheduling with stochastic recovery time: a new track-backup approach, IEEE Trans. Syst. Man Cybern. Syst. 44 (9), 2014.

13. Liu R., Li S., Yang L.: Collaborative optimization for metro train scheduling and train connections combined with passenger flow control strategy. Omega 2018, DOI 10.1016/j.omega.2018.10.020. 
14. Policella N., Smith S.F., Cesta A., Oddi A.: Generating Robust Schedules through Temporal Flexibility. ICAPS'04 Proceedings of the Fourteenth International Conference on International Conference on Automated Planning and Scheduling, Whistler, British Columbia, Canada, 2004.

15. Policella N.: Scheduling with uncertainty: a proactive approach using partial order schedules. PhD thesis, Dipartimento di Informatica e Sistemistica, Università degli Studi di Roma, Rome, Italy, 2005.

16. Salido M.A., Barber F., Ingolotti L.: Robustness in railway transportation scheduling. In: 2008 7th World Congress on Intelligent Control and Automation. Chongqing, China, 2008.

17. Schöbel A., Kratz, A.: A bicriteria approach for robust timetabling. In: Ahuja et al. (eds.), Robust and online large-scale optimization, LNCS, Vol. 5868, 2009.

18. Takeuchi Y., Tomii N.: Robustness indices for train rescheduling. In: CDROM Proceedings of the 1st International Seminar on Railway Operations Modelling and Analysis. Delft, the Netherlands, 2005.

19. Waschneck B., Reichstaller A., Belzner L., Altenmüller T., Bauernhansl T., Knapp A., Kyek A.: Optimization of global production scheduling with deep reinforcement learning, Procedia CIRP, Vol. 72, 2018, DOI 10.1016/j.procir.2018.03.212. 


\section{OCENA HARMONOGRAMU PRACY DRUŻYN POCIĄGOWYCH W ASPEKCIE ODPORNOŚCI}

\section{Wstęp}

W literaturze wyróżnia się różne miary badające własności harmonogramów. Miary odporności chronometraży można podzielić w zależności od stopnia wdrożenia. Środki ex ante związane są z charakterystyką rozkładu jazdy lub planu pracy na etapie planowania. Natomiast środki ex post oparte są na warunkach ruchowych po wdrożeniu rozwiązania do realizacji. Na etapie aplikacji planu do systemu rzeczywistego wskaźniki są skorelowane ze stopniem odporności na zakłócenia harmonogramów dostępnych w wygenerowanych rozwiązaniach tymczasowych będących odpowiedzią na zakłócenia. Autorzy publikacji głównie koncentrują się na zakłóceniach czasowych, czyli sytuacjach, w których przejazd trwa dłużej niż oczekiwano lub czas rozpoczęcia działania jest opóźniony. Zauważono także problem „efektu domina” w przypadku wystapienia zakłóceń. Podczas realizacji harmonogramów pracy drużyn konduktorskich przy obecnych praktykach duży wpływ mają działania zależne oraz czynnik ludzki w postaci dyspozytora. Decyduje on o zmianie planu pracy poszczególnych drużyn w przypadku braku możliwości przesiadki do zaplanowanego taboru. Poprawa odporności na zakłócenia harmonogramów pracy drużyn polega m.in. na ciągłej analizie procesów, inwentaryzowaniu występujących zakłóceń oraz prognozowaniu ich skutków. Do właściwego planowania pracy wskazane są najdokładniejsze dane o aktualnym systemie pozwalające na prognozę możliwości wystapienia stanów krytycznych.

\section{Odporność harmonogramów}

Pojęcie odporności (ang. robustness) stosowne jest w różnych dziedzinach nauki. W zależności od dziedziny charakteryzuje się ono innym znaczeniem. Jego początki sięgają czasów nowoczesnej teorii decyzyjnej opracowanej w latach 50 . XX wieku i zastosowania analizy niepożądanych scenariuszy oraz modelu Maximina Walda jako narzędzia do zapobiegania przypadkom niestabilnym. W latach 
70. odporna optymalizacja (ang. robust optimization) stała się samodzielną dyscypliną, równolegle rozwijając się w kilku dziedzinach naukowych i technologicznych. Pojęcie odporności przez lata było stosowane w statystyce i badaniach operacyjnych [1].

W planowaniu odporność odnosi się do harmonogramu pracy maszyn, ludzi i pojazdów. Według [18] oznacza możliwość poradzenia sobie z nieoczekiwanymi problemami bez znaczących modyfikacji harmonogramu. W artykule [15] odporność określana jest jako tolerancja dla pewnego stopnia niepewności, natomiast w [17] jest to maksymalne początkowe opóźnienie możliwe do wystąpienia bez powodowania zakłóceń innych pojazdów. Definicja ta odnosi się do projektowania rozkładów jazdy oraz harmonogramów pracy drużyn konduktorskich i maszynistów. Ich harmonogram jest z nim ściśle związany. W [2] autorzy definiują odporność jako zdolność harmonogramu do przeciwstawiania się błędom projektowym, zmianom parametrów i warunków operacyjnych. Autor publikacji [9] zdefiniował harmonogram jako odporny, gdy opóźnienia z jednego okresu nie rozprzestrzeniają się na kolejny okres. Podejście opiera się na tym, że harmonogram jest okresowy. W [16] odporność odnosi się do „odporności na niedokładność”. Przedstawiono dwie definicje odporności. Pierwsza definicja to odsetek zakłóceń mniejszych niż określona jednostka czasu, którą rozkład jazdy jest w stanie tolerować bez jakichkolwiek bieżących modyfikacji. Zakłócenie odnosi się tutaj do jednego pojedynczego zdarzenia (opóźnienia) w realizacji harmonogramu. Druga definicja dotyczy tego, czy harmonogram może powrócić do początkowego etapu niezmienionego zakłóceniem w ograniczonym czasie.

W dziedzinie planowania problem dotyczący odporności może mieć różne źródła: nieprecyzyjnie określone czasy trwania czynności, zmniejszona pojemność zasobów (np. z powodu awarii maszyn), nowe zadania produkcyjne, zmiana kolejności działań i operatorów. Rozwiązaniem problemu związanego z harmonogramowaniem jest uwzględnienie oddziaływania zdarzeń zewnętrznych. Gwarantuje to stabilność działania elastycznych harmonogramów. W czasie wystapienia zakłócenia elastyczny harmonogram umożliwia alokację działań. Stanowi to podstawę do odpowiedzi na nieoczekiwane zakłócenia. W artykule [15] skoncentrowano się na zbudowaniu częściowo gotowych rozwiązań (czasowo spójnych), które są również częścią harmonogramu całościowego. Celem nie jest ułożenie jednego harmonogramu, ale zdefiniowanie zestawu harmonogramów, które nazywane są harmonogramem zdarzeń częściowych (POS). Planowanie POS dla danego problemu to wykres, w którym znajdują się węzły będące czynnościami, a krawędzie oznaczają częściowe ograniczenia między parami działań, takie że dowolne rozwiązanie tymczasowe możliwe w danej chwili do zastosowania jest spójne z całym harmonogramem. 
Autorzy [15] używają terminu „odporność” jako zdolności harmonogramu do przyjmowania niewielkich opóźnień. Odporny harmonogram to taki, który pozwala odzyskać pociagom punktualność po wystapieniu małych opóźnień i zapobiega rozprzestrzenianiu się zakłóceń w sieci. Wyzwanie w tworzeniu odpornych rozkładów jazdy jest dwojakie: wymagana jest miara wiarygodności, która dokładnie oddaje możliwość zrealizowania harmonogramu, a także metoda sugerująca, jak zmodyfikować harmonogram w celu zwiększenia odporności zgodnie z innymi określonymi celami planowania. Zanim harmonogram zostanie zaimplementowany w środowisku symulacyjnym lub zrealizowany w rzeczywistości, trudno jest przewidzieć, jak ruch kolejowy zareaguje na zakłócenia i jakiej wielkości opóźnienia mogą wystapić. W europejskich sieciach przewozów kolejowych występuje duża zajętość szlaków w wielu punktach sieci. Konsekwencją tego jest wrażliwy na opóźnienia system ruchu z małą odpornością na zakłócenia. Jednym z podstawowych wyzwań jest ocena jego odporności i wyznaczenie strategii mających na celu zmniejszenie wrażliwości na zakłócenia. Najpopularniejszym sposobem jest analiza harmonogramu pod kątem przepustowości odstępów i eliminacja newralgicznych punktów krytycznych. Istniejące miary odporności są przydatne przy porównywaniu różnych rozkładów jazdy w odniesieniu do ich odporności. Nie sąjednak tak użyteczne, aby sugerowały bezpośrednio, w jakich punktach należy wprowadzić usprawnienia. Autorzy [15] proponują nowy wskaźnik uwzględniający pojęcie krytyczne. Określony jest on jako odwrotność sumy najkrótszych różnic odległości między pojazdami. Koncepcja ta pozwala znaleźć słabe punkty w harmonogramie. W celu ilościowej oceny, jak krytyczny jest punkt, określana jest miarodajność w punktach krytycznych. Przedstawiono wyniki ze studiów eksperymentalnych, w których wykonano benchmark punktów krytycznych. Wnioskami z oceny była konieczność zwrócenia uwagi na punkty w rozkładach jazdy, w których pociągi wjeżdżają na linię kolejową lub się wyprzedzają. Z punktu odporności ważna jest różnica czasu pomiędzy nimi. Zaproponowano także opóźnianie pociągów już opóźnionych przez wydłużenie postojów na stacjach w celu przepuszczenia pociągów jadących punktualnie.

W transporcie kolejowym kwestie odporności można podzielić na związane z rozkładem jazdy i harmonogramem pracy ludzi oraz taboru. Charakter problemu bieżącej modyfikacji rozkładu jazdy jest wielozadaniowy ze względu na liczne sprzeczne wykorzystanie zasobów oraz kwestie dotyczące zapewnienia jakości dla pasażerów. W związku z tym podejścia oparte na wielu celach generują więcej odpornych działań alternatywnych [8].

Zakłócenia powodują opóźnienie pierwotne jednego pociągu, który często propaguje je na inne składy, jako drugorzędne. W związku z tym, jednym z głównych 
wymogów jest ograniczenie propagowania opóźnień drugorzędnych w sieci. Strategie związane $\mathrm{z}$ odpornością odpowiedzi na zakłócenie dzielą się na strategie a priori i a posteriori:

- możliwość absorbcji opóźnień pierwotnych poprzez uwzględnienie buforów czasowych na etapie projektowania (a priori) zapewnia większą elastyczność harmonogramu,

- zmniejszanie opóźnień wtórnych poprzez działania dyspozytorskie (a posteriori) $[6,7,10,12]$.

\section{Wskaźniki odporności stosowane w transporcie kolejowym}

Miary odporności rozkładu jazdy pociągów można podzielić na dwie grupy: środki ex ante, związane z charakterystyką rozkładu jazdy, oraz środki ex post, które są oparte na warunkach ruchowych. Środki odpowiadające za warunki ruchowe nie mogą być obliczane, chyba że harmonogram został zrealizowany w rzeczywistości lub zasymulowany wraz z zakłóceniami. Środki dotyczące charakterystyki rozkładu jazdy można obliczyć i porównać już na wczesnym etapie planowania bez znajomości zakłóceń. Rys. 1 przedstawia podstawową różnicę między dwiema grupami.

W celu oceny odporności harmonogramów alternatywnych układanych po wystąpieniu zakłócenia, w publikacjach $[4,14]$ wprowadzono dwie miary, które badają ich własności. Pierwsza metryka fldt (1) jest skorelowana ze stopniem odporności harmonogramu dostępnego w wygenerowanych rozwiązaniach. Im większa wartość współczynnika fldt, tym mniejsza szansa wystapienia „efektu domina”. Wskaźnik dsrp (2) może być alternatywnie postrzegany jako wynik symulacji rozwiązania będącego odpowiedzią na jedno zdarzenie niepożądane.

$$
f l d t=\sum_{h \neq 1} \frac{\left|d\left(e_{a h}, s_{a l}\right)+d\left(s_{a l}, e_{a h}\right)\right|}{H \cdot n \cdot(n-1)} \cdot 100
$$

$H$ - horyzont problemu (czas trwania wszystkich działań)

$n$ - liczba czynności

$d\left(\mathrm{t}_{\mathrm{p} 1}, \mathrm{t}_{\mathrm{p} 2}\right)-$ czas pomiędzy dwoma punktami w czasie

$$
d s r p=\frac{1}{n} \sum_{i=1}^{n} \frac{\text { slack }_{a i}}{\text { num }_{\text {changes }\left(a_{i}, \Delta a_{i}\right)}}
$$


Slack $_{a \mathrm{i}}$ - czasowa elastyczność każdej aktywności (zdolność do zaabsorbowania zmian)

Num - efekt propagacji liczby przeniesionych działań

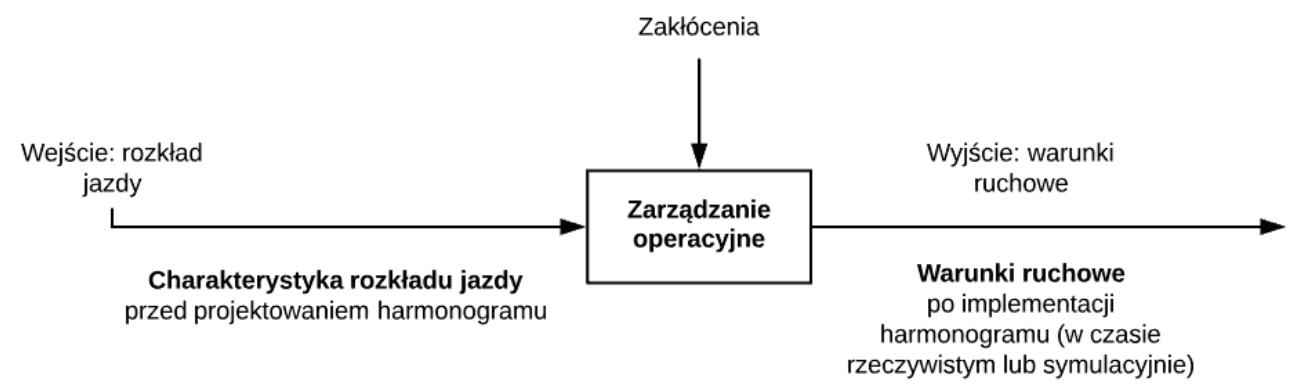

Rys. 1. Miary odporności rozkładu jazdy ex ante i ex post

Autorzy publikacji koncentrują się wyłącznie na zakłóceniach czasowych (sytuacjach, w których przejazd trwa dłużej niż oczekiwano, lub czas rozpoczęcia działania jest opóźniony). Przy ocenie nie są analizowane powiązania pomiędzy poszczególnymi działaniami.

\section{Działania zależne}

Przesiadki w transporcie kolejowym mogą być zdefiniowane jako działania zależne. Tego typu powiązania $\mathrm{w}$ harmonogramie uwzględnia się $\mathrm{w}$ obszarze planowania produkcji. Polegają one na wytwarzaniu danego elementu na kilku maszynach w ciągu technologicznym $[5,19]$. Łańcuch ten cechuje się większą elastycznością (łatwością reorganizacji) i nie występują tam takie ograniczenia jak w transporcie kolejowym. Według [13] przesiadki pomiędzy pociagami są ograniczane rozkładem jazdy, do którego przypisany jest tabor, i harmonogramami pracy drużyn pociaggowych. Warunki infrastrukturalne i czas przejazdu w połączeniu z częstotliwością kursowania taboru są kolejnym ograniczeniem. W przypadku wystąpienia zakłóceń w zależności od infrastruktury pociagi mogą oddziaływać na siebie. Systemy sztywnotorowe są ściśle związane z wyznaczonym torem jazdy [11]. Według [3] zarządzanie ruchem kolejowym i jego reorganizacja w przypadku wystapienia zakłócenia jest kluczowe dla zapewnienia pasażerom wysokiej jakości usług. Harmonogram pracy drużyn konduktorskich charakteryzują następujące parametry: 
- czas podróży,

- czas obowiązków pracy,

- czas przerwy,

- czas czynności związanych z przygotowaniem do pracy,

- czas czynności związanych z zakończeniem pracy,

- czas reorganizacji harmonogramu,

- służby zaczynające się w gnieździe,

- służby kończące się w gnieździe,

- służby zaczynające się na stacjach,

- służby kończące się na stacjach,

- zestaw podróży zależnych,

- zestaw podróży w ramach obiegu taboru (sekwencyjnych),

- zestaw wszystkich podróży,

- czasy przejścia drużyn (pomiędzy pociągami, do gniazda i z gniazda),

- czas przejęcia i zdania pociagu, ewentualnej próby hamulców,

- możliwy maksymalny czas trwania podróży,

- minimalny czas trwania podróży,

- godzina odjazdu,

- godzina przybycia,

- maksymalny czas trwania zmiany,

- minimalny czas trwania zmiany,

- czas zmiany przeznaczony na jazdę,

- czas trwania zmiany generujący rozprzestrzenianie się zakłóceń.

Za pomocą uogólnionej sieci Petriego o znakowaniu początkowym $\mathrm{M}_{0}=(1,0$, $0,0,0,1,1)$ zamodelowano w sposób niedeterministyczny proces przesiadki (rys. 2). Sieć ta osiaga trzy martwe znakowania interpretowane jako objęcie składu pociagu przez drużynę konduktorską po zakończonej przesiadce. Jest ona zachowawcza, gdyż w trakcie pracy nie ulega zmianie liczba znaczników.

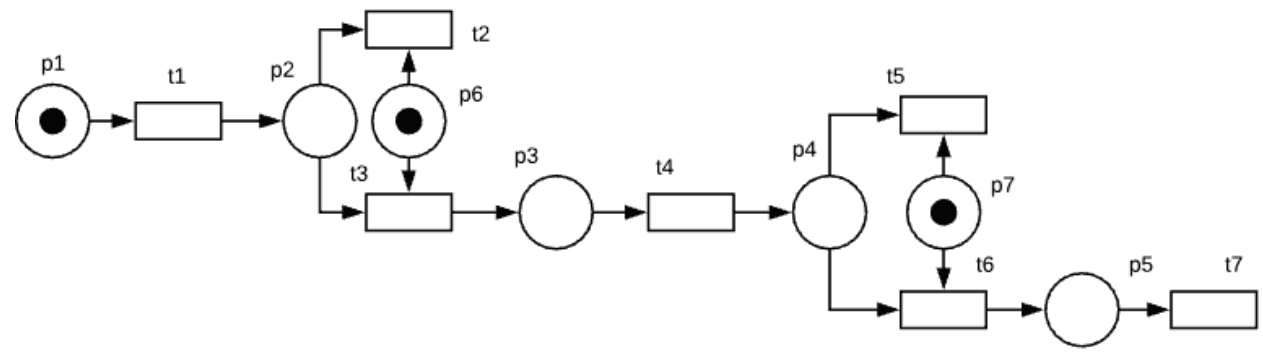

Rys. 2. Niedeterministyczny model przesiadki z wykorzystaniem sieci Petriego 
Poniżej znajduje się wyjaśnienie oznaczeń zastosowanych na rys. 2:

$\mathrm{p}_{1}-\mathrm{jazda} \mathrm{w}$ pociagu,

$\mathrm{p}_{2}$ - przesiadka,

$\mathrm{p}_{3}-$ kontakt $\mathrm{z}$ dyspozytorem,

$\mathrm{p}_{4}$ - informacja o przesiadce,

$\mathrm{p}_{5}$ - wysiadka z pociagu dojazdowego,

$\mathrm{p}_{6}$ i $\mathrm{p}_{7}$ - zapewniają wybór jednej ścieżki,

$\mathrm{t}_{1}$ - wysiadka,

$\mathrm{t}_{2}$ - objęcie składu według harmonogramu (punktualnie),

$\mathrm{t}_{3}$ - niemożliwość objęcia składu według harmonogramu,

$\mathrm{t}_{4}$ - szukanie przesiadki,

$\mathrm{t}_{5}$ - objęcie wskazanego składu,

$\mathrm{t}_{6}$ - jazda do innego punktu na przesiadkę,

$\mathrm{t}_{7}-$ objęcie składu.

\section{Analiza harmonogramów dla stacji węzłowej}

W ramach przykładu przeanalizowano pod kątem odporności na opóźnienia harmonogram pracy drużyn z przesiadkami przewoźnika lokalnego krótkodystansowego dla jednej ze stacji węzłowych. Tego typu przewozy charakteryzują się dużą elastycznością dostępnych połączeń i częstymi postojami w porównaniu z relacjami dalekobieżnymi.

W celu określenia wartości opóźnień mogących zakłócić wykonanie harmonogramu dokonano pomiarów punktualności dla 9608 pociąó́w tego przewoźnika (tab. 1).

Tabela 1

Charakterystyka danych operacyjnych o opóźnieniach

\begin{tabular}{|c|c|c|}
\hline $\begin{array}{c}\text { Liczba analizowanych } \\
\text { pociągów }\end{array}$ & Odjazdy punktualne & Odjazdy opóźnione \\
\hline 9608 & 0,6168 & 0,3832 \\
\hline
\end{tabular}

Na rys. 3 przedstawiono rozkład prawdopodobieństwa odjazdu pociagu ze stacji z opóźnieniem większym niż zero, to znaczy później niż planowo według rozkładu jazdy. Rozkład gamma oszacowano i potwierdzono testem chi-kwadrat na poziomie istotności 0,05 . Ostatecznie do opisu opóźnień w analizowanym scenariuszu wykorzystano rozkład gamma $\Gamma(0,78273,7,538)$ o funkcji gęstości prawdopodobieństwa (3). 


$$
f(x)=\frac{x^{\alpha-1}}{\beta^{\alpha} \Gamma(\alpha)} \exp \left(-\frac{x}{\beta}\right)
$$

$\Gamma$ - funkcja Gamma,

$\alpha$ - parametr kształtu $(\alpha>0)$,

$\beta$ - parametr skali $(\beta>0)$.

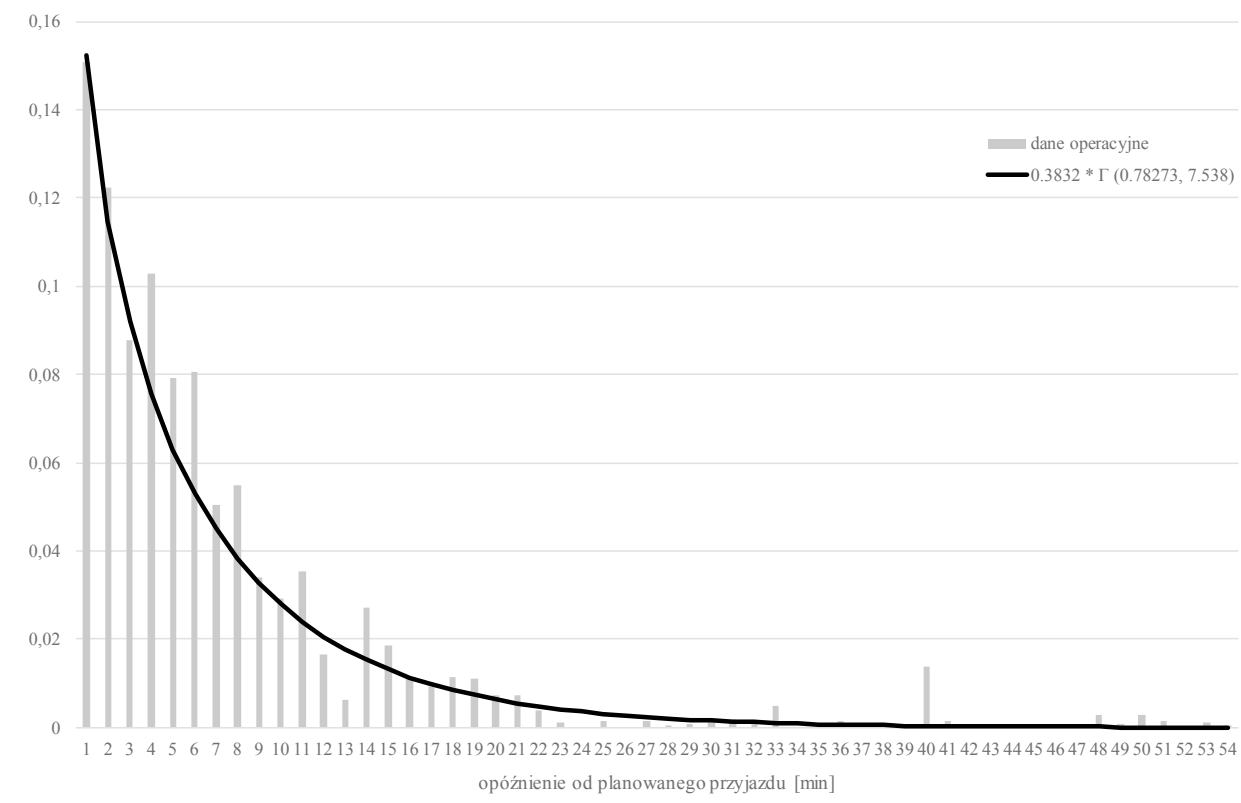

Rys. 3. Rozkład empiryczny opóźnień i przybliżony rozkład gamma

Prawdopodobieństwo nieopóźnienia pociagu obliczano w następujący sposób (4):

$$
P_{o}=0,6168+0,3832 \cdot \int_{0}^{t} f(x) d x
$$

gdzie $f(x)$ jest funkcją gęstości prawdopodobieństwa opisującą opóźnienia pociągów, w tym przypadku $\Gamma(0,78273,7,538)$, gdzie górna granica $t$ oznacza różnicę między planowym zakończeniem pierwszego procesu a najpóźniejszym zakończeniem drugiego.

W celu weryfikacji czasu potrzebnego na przesiadkę drużyny konduktorskiej na analizowanej stacji przeprowadzono pomiary czasów przejścia od chwili zatrzymania pociagu pierwszego do momentu wejścia drużyny do pociagu docelowego (drugiego) (tab. 2). 


\section{Tabela 2}

Charakterystyka danych operacyjnych czasów przesiadek

\begin{tabular}{|c|c|c|}
\hline $\begin{array}{c}\text { Liczba zmierzonych } \\
\text { przesiadek }\end{array}$ & Wartość średnia [min] & $\begin{array}{c}\text { Odchylenie standardowe } \\
\text { [min] }\end{array}$ \\
\hline 30 & 6 & 2,19 \\
\hline
\end{tabular}

Wyznaczono przedział ufności średniego czasu przejścia drużyny (5), przyjmując współczynnik ufności 0,95 . Czas potrzebny na przesiadkę na badanej stacji mieści się w przedziale od 5,22 do 6,78 min.

$$
P(5,22<v<6,78)=0,95
$$

Poszczególne czynności zależne poprzedzające i następujące po przesiadce drużyny zostały graficzne zaprezentowane na rys. 4 . W pierwszej kolejności drużyna konduktorska jedzie pociągiem 69551, z którego będzie wysiadać na stacji i przesiadać się do pociągu 69552. W przypadku punktualnego przyjazdu obu pociągów czas pomiędzy przyjazdem pociagu 69551 a odjazdem pociagu 69552 jest większy od zmierzonego czasu rzeczywistego potrzebnego na przesiadkę. Jako „przesiadka” określany jest fizyczny czas od momentu wyjścia z pociągu 69551 do momentu wejścia do pociagu 69552 drużyny. Bufor wiąże się z czasem bezpieczeństwa, który jest wykorzystywany w przypadku zdarzeń zakłócających dla poprawienia odporności harmonogramu. Jeżeli pociag 69551 albo 69552 będzie opóźniony o wartość bufora albo mniejszą lub sumaryczne opóźnienie obu pociagów będzie równe bądź mniejsze od wartości bufora, przesiadka drużyny konduktorskiej będzie wykonalna. W sytuacji gdy nastąpi zakłócenie tego procesu spowodowane większym opóźnieniem pociagu 69551, nastapi konieczność opóźnienia odjazdu pociągu 69552.

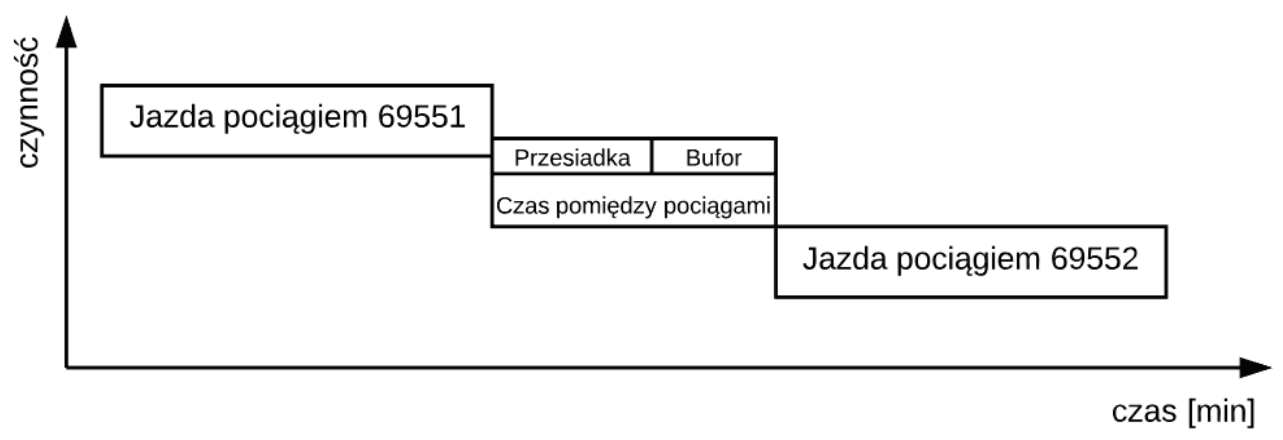

Rys. 4. Przesiadka pomiędzy dwoma pociaggami 69551 i 69552 
Przykładowe harmonogramy pracy zawierające działania zależne zostały zbadane w aspekcie odporności na niepunktualność. Pojęcie to zdefiniowano jako stopień tolerancji dla opóźnienia pociągu niepowodujący zmian realizacji harmonogramu pracy drużyn i biegu innych pociaggów. Czasy na przesiadkę nie są w żaden sposób określone w przepisach kolejowych. Przewoźnicy wyznaczają je w sposób intuicyjny. Na rys. 5 przedstawiono zestawienie czasów pomiędzy pociagami dla 10 analizowanych służb z zaplanowanymi przesiadkami na wybranej stacji węzłowej w porównaniu z czasem buforowym, czyli wartością czasu pomiędzy pociągami pomniejszoną o górną granicę wyznaczonego przedziału ufności dla rzeczywistego czasu realizacji przesiadki na tej stacji. Każda ze służb charakteryzuje się innym czasem buforowym.

Obliczono wartości prawdopodobieństwa nieopóźnienia pociagu (4) w zależności od czasów buforowych uwzględnionych w 11 harmonogramach dla analizowanej stacji węzłowej. Wyniki znajdują się na rys. 6. Czasy buforowe od $20 \mathrm{~min}$ dla analizowanych danych dają największą gwarancję, że poprzedni proces zakończy się o czasie i nie opóźni kolejnego. Dla bufora wynoszącego 1 min prawdopodobieństwo opóźnienia kolejnego pociagu, do którego przesiada się drużyna, przez poprzedni pociąg, który może być opóźniony, jest największe i wynosi 0,3 .

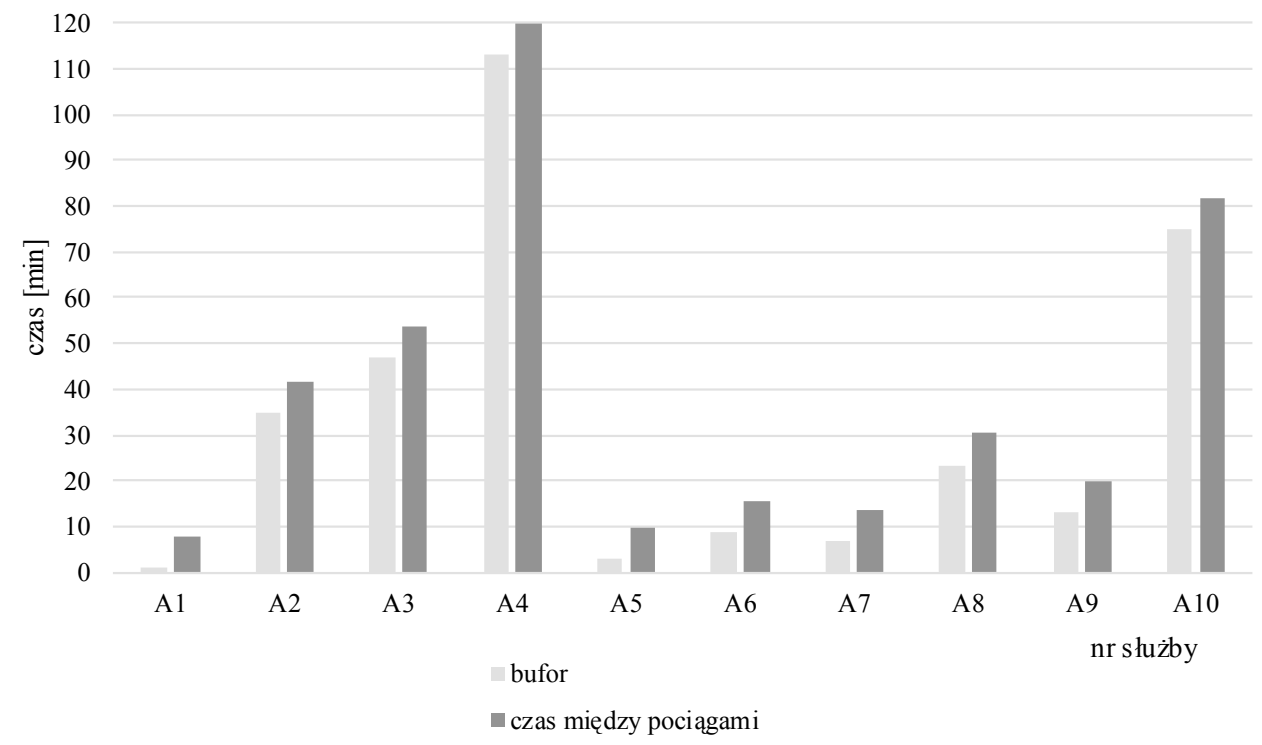

Rys. 5. Porównanie czasów między pociagami uwzględnionych w analizowanych służbach z czasem buforowym 


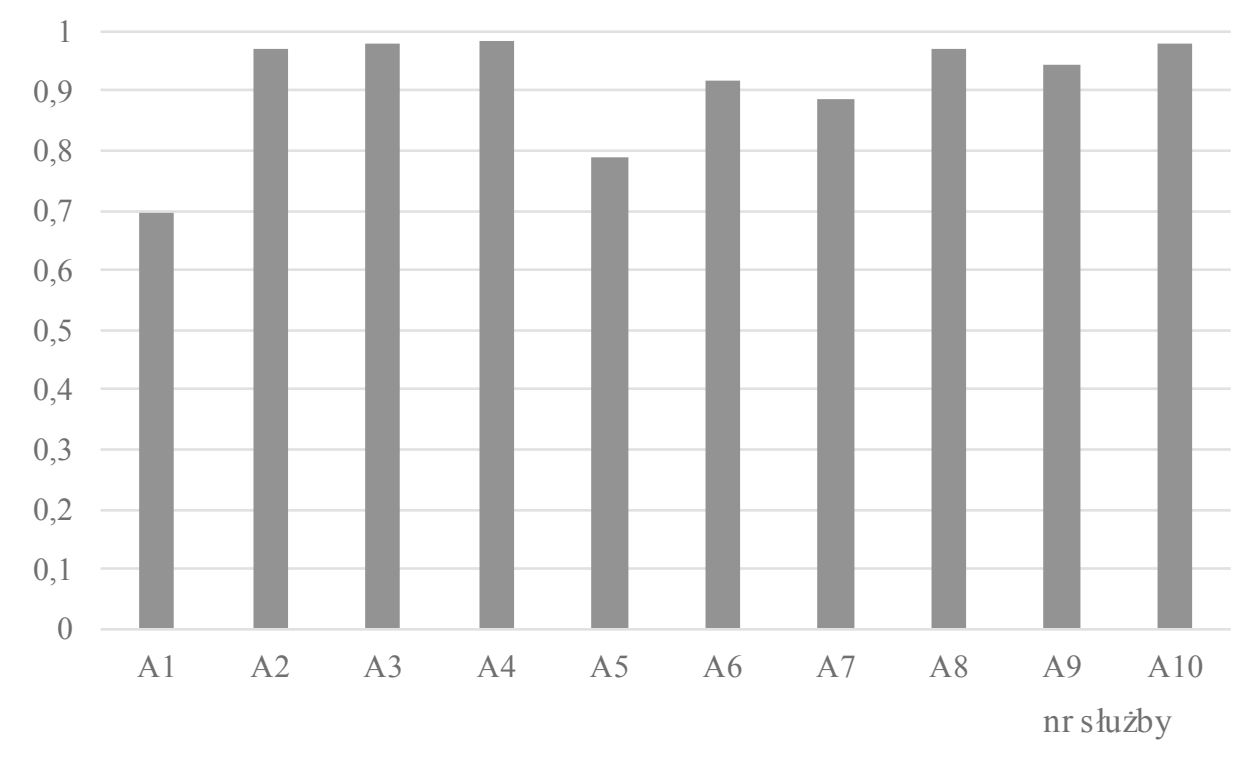

Rys. 6. Prawdopodobieństwo nieopóźnienia kolejnego pociąu przez poprzedni

Prawdopodobieństwo realizacji przesiadki wyznacza słabe ogniwa planu pracy wskazujące na konieczność jego modyfikacji, w ten sposób stając się kryterium decyzyjnym. Istnieją metody pozwalające na eliminowanie propagacji opóźnień w przypadku oddziaływania dwóch pociagów. W przypadku gdy pociągi jadą z kierunków przeciwnych, a drużyny się wymieniają, można pociąg jadący punktualnie wyprawić w dalszy bieg i przesunąć przesiadkę na stację kolejną. W sytuacjach większych opóźnień można zastosować metodę przesunięć schodkowych. Polega ona na przejmowaniu pociągów późniejszych przez kolejne opóźnione drużyny.

\section{Podsumowanie}

Przeprowadzone badania opóźnień pociągów i rzeczywistego czasu przesiadki na stacji węzłowej posłużyły do oceny skutków zdarzeń zakłócających harmonogram pracy drużyn konduktorskich. Ze względu na duże czasy buforowe harmonogram ten charakteryzuje się wysokim stopniem odporności na zakłócenia działań zależnych. W rozważanym przypadku problemy z przesiadką mogą wystąpić dla 
czasu buforowego poniżej 8 min, który jest zastosowany w trzech służbach. Przesiadki w pozostałych służbach charakteryzują się prawdopodobieństwem nieopóźnienia kolejnego pociagu na poziomie 0,9 .

Wynika $\mathrm{z}$ tego, że w przypadku wprowadzenia do harmonogramów przesiadek ważne jest zaimplementowanie odpowiednich dla warunków ruchowych czasów buforowych. Analizowany harmonogram charakteryzuje się długimi czasami buforowymi o średniej wartości $33 \mathrm{~min}$.

W perspektywie kolejnych badań planowane jest zautomatyzowanie narzędzia oceny do postaci wspomagającej konstrukcję harmonogramów na podstawie archiwalnych danych o zdarzeniach zakłócających.

\section{Literatura}

1. Bertsimas D., Sim M.: The Price of Robustness. Operations Research, 52 (1), 2004.

2. Bešinovic N., Goverde R., Quaglietta E., Roberti R.: An integrated micro-macro approach to robust railway timetabling. Transportation Research, Part B 87, 2016.

3. Castillo E., Gallego I., Urena J.M., Coronado J.M.: Timetabling optimization of a mixed double- and single-tracked railway network. Appl. Math. Model. Vol. 35, 2011.

4. Cesta A., Oddi A., Smith S.F.: Profile Based Algorithms to Solve Multiple Capacitated Metric Scheduling Problems. In Proceedings of the 4th International Conference on Artificial Intelligence Planning Systems AIPS-98, 241-223. AAAI Press, 1998.

5. Chergui A., Hadj-Hamou K., Vignat F.: Production scheduling and nesting in additive manufacturing. Computers \& Industrial Engineering, Vol. 126, 2018, DOI 10.1016/j.cie.2018.09.048.

6. D'Ariano A., Pacciarelli D., Pranzo M.: Assessment of flexible timetables in real-time traffic management of a railway bottleneck. Transp. Res. C Emer. 16 (2), 2008.

7. Dewilde T., Sels P., Cattrysse D., Vansteenwegen P.: Defining robustness of a railway timetable. Proceedings of the Fourth International Seminar on Railway Operational Modelling and Analysis RailRome, 2011.

8. Fang W., Yang S., Yao X.: A survey on problem models and solution approaches to rescheduling in railway networks. IEEE Trans. Intell. Transp. Syst. 16 (6), 2015.

9. Goverde R.: Railway timetable stability analysis using max-plus system theory. Transp. Res. Part B 41, 2007.

10. Kroon L.G., Huisman D., Maróti G.: Optimisation models for railway timetabling. In: I. Hansen, J. Pachl (Eds.) Railway Timetable and Traffic, Eurailpress, Hamburg 2008.

11. Kuznetsov N.A., Minashina I.K., Pashchenko F.F., Ryabykh N.G., Zakharova E.M.: Design and Analysis of Optimization Algorithms for Multi-agent Railway Control System. Procedia Computer Science, Vol. 37, 2014, DOI 10.1016/j.procs.2014.08.032.

12. Li X., Shou B., Ralescu D.: Train rescheduling with stochastic recovery time: a new track-backup approach, IEEE Trans. Syst. Man Cybern. Syst. 44 (9), 2014. 
13. Liu R., Li S., Yang L.: Collaborative optimization for metro train scheduling and train connections combined with passenger flow control strategy. Omega 2018, DOI 10.1016/j.omega.2018.10.020.

14. Policella N., Smith S.F., Cesta A., Oddi A.: Generating Robust Schedules through Temporal Flexibility. ICAPS'04 Proceedings of the Fourteenth International Conference on International Conference on Automated Planning and Scheduling, Whistler, British Columbia, Canada, 2004.

15. Policella N.: Scheduling with uncertainty: a proactive approach using partial order schedules. PhD thesis, Dipartimento di Informatica e Sistemistica, Università degli Studi di Roma, Rome, Italy, 2005.

16. Salido M.A., Barber F., Ingolotti L.: Robustness in railway transportation scheduling. In: 2008 7th World Congress on Intelligent Control and Automation. Chongqing, China, 2008.

17. Schöbel A., Kratz, A.: A bicriteria approach for robust timetabling. In: Ahuja et al. (eds.), Robust and online large-scale optimization, LNCS, Vol. 5868, 2009.

18. Takeuchi Y., Tomii N.: Robustness indices for train rescheduling. In: CDROM Proceedings of the 1st International Seminar on Railway Operations Modelling and Analysis. Delft, the Netherlands, 2005.

19. Waschneck B., Reichstaller A., Belzner L., Altenmüller T., Bauernhansl T., Knapp A., Kyek A.: Optimization of global production scheduling with deep reinforcement learning, Procedia CIRP, Vol. 72, 2018, DOI 10.1016/j.procir.2018.03.212. 